\title{
Letter to editor: Current and future techniques for human papilloma virus (HPV) testing in oropharyngeal squamous cell carcinoma
}

\author{
Ali Qureishi ${ }^{1}$ (1) $\cdot$ Stuart Winter ${ }^{1}$
}

Received: 6 July 2017 / Accepted: 12 July 2017 / Published online: 25 July 2017

(c) Springer-Verlag GmbH Germany 2017

\section{Dear Editor,}

Thank you for the opportunity to respond to a letter written by one of your readers on our paper titled 'Current and future techniques for human papilloma virus (HPV) testing in oropharyngeal squamous cell carcinoma (OPSCC)' [1]. This article aimed to provide the practising head and neck surgeon with a working knowledge of techniques available for HPV testing in OPSCC. With an overall aim of increasing compliance with guidelines for HPV testing in patients with OPSCC, we discussed seven different techniques for detecting HPV in patients with OPSCC, including combination tests and five different diagnostic sources of material. We concluded that HPV testing in the context of OPSCC was complex, that there was sufficient evidence to support the use of combination testing and that further evaluation of non-invasive techniques was required.

Your reader describes a technique for HPV detection and subtyping using DNA microarray (a combination of PCR and DNA chip testing) and concludes that this technique 'has proper accuracy' for detecting known HPV subtypes in OPSCC. Whilst this may be the case, the diagnostic accuracy of a test should be determined in the target patient population. We were unable to find the evidence base for this conclusion as the studies referenced by your reader relate to an unpublished study in oral cancer patients [2] and a study in patients with cervical cancer [3].

This reply refers to the article available at doi:10.1007/s00405-017-4662-0.

\section{Ali Qureishi}

aliqureishi@googlemail.com

1 Department of Otolaryngology, Oxford University Hospitals NHS Trust, Oxford, UK
Whilst, DNA microarray may prove beneficial in determining the presence of clinically relevant HPV in patients with OPSCC. Without evaluating the results of a welldesigned diagnostic accuracy study, we are unable to agree with the conclusions of your reader.

\section{Compliance with ethical standards}

Ethical approval This article does not contain any studies with human participants performed by any of the authors.

Conflict of interest The authors have no conflicts of interest to declare.

\section{References}

1. Qureishi A, Mawby T, Fraser L, Shah KA, Moller H, Winter S (2017) Current and future techniques for human papilloma virus (HPV) testing in oropharyngeal squamous cell carcinoma. Eur Arch Otorhinolaryngol. doi:10.1007/s00405-017-4503-1

2. Kim SM KI, Myoung H, Lee JH, Lee SK (2017) Human papillomavirus (HPV) in Korean oral cancer patients using microarray technology. Human Pathol (submitted)

3. Lim YK, Choi JH, Park S, Kweon OJ, Park AJ (2016) Comparison of three different commercial kits for the human papilloma virus genotyping. J Clin Lab Anal 30(6):1110-1115. doi:10.1002/jcla.21989 